\title{
Russian Market Power in International Wheat Exports: Evidence from a Residual Demand Elasticity Analysis
}

\author{
${ }^{1}$ Department Agricultural Markets, Leibniz Institute of Agricultural Development in Transition Economies (IAMO), Theodor- \\ Lieser-Str. 2, 06120 Halle (Saale), Cermany, E-mail: uhl@iamo.de
}

\begin{abstract}
:
Russia has emerged as a major wheat exporter since the beginning of the 2000s, and today, it possesses high market shares in several wheat-importing countries in the Middle East and North African region. This has raised concerns that Russia might abuse its dominant market position by pricing above marginal cost. Using a novel dataset with weekly information on Russian wheat exports, we apply the residual demand elasticity method to analyze the pricing behavior of Russia in its two most important export markets, i. e. Egypt and Turkey. Our estimation results reveal that Russia behaves competitively in Egypt while it exerts market power in Turkey with an estimated mark-up of $13.5 \%$.
\end{abstract}

Keywords: Russian wheat exports, market power, residual demand elasticity approach

DOI: 10.1515/jafio-2016-0026

\section{Introduction}

Recent years have witnessed unstable food commodity prices in international markets (see Wright 2011). Notably, prices of staple foods, such as wheat, maize, and rice, were subject to significant increases and fluctuations. The price index comprising monthly average world market prices of wheat, rice, maize and soybean soared by $226 \%$ from January 2002 until June 2008, and by $70 \%$ from June 2010 until March 2011 (Trostle et al. 2011). In more detail, prices of wheat rose by $127 \%$, of maize even by almost $300 \%$ and of rice by $170 \%$ from January 2005 until the price peak in June 2008 (Mitchell 2008). The FAO Cereals Price Index, comprising price information on wheat, maize and rice, shows that cereal prices have been persistently higher since 2006 with price peaks in 2006/07 and 2010/11. After the 2011 price peak, cereal prices have been declining, yet remaining substantially above the pre-2006 price level. Abbott, Hurt, and Tyner (2011) point out that the price elasticity of demand for staple foods has been lower in recent years than previously contributing to price volatility. A less price-responsive demand might enable exporters to better exploit a dominant market position since the Lerner index as a measure for the exertion of market power is a function of the price elasticity of demand. Uhl, Perekhozhuk, and Glauben (2016) argue that prices of staple foods are less price-responsive in years of scarcity. The issue of market power is therefore particularly relevant in times of scarcity and high prices. Wheat exporters exploiting market power may contribute to rising and volatile prices and hence significantly affect food security in the developing world (Uhl, Perekhozhuk, and Glauben 2016).

Oligopolistic market structures are a source of market power, and the global wheat market is undoubtedly supplied by a few exporting nations. Competition among these states is restricted by geography as wheat belongs to the category of bulky products that always involve substantial transportation costs when traded. Geographic proximity thus might imply pricing power. Russia has entered the global wheat market at the beginning of the 2000 and since then has established itself as a major wheat exporter. Today, Russia possesses a dominant position in several wheat-importing countries in the Middle East and North African region (MENA). Uhl, Perekhozhuk, and Glauben (2016) describe the Russian wheat export market for the period 1998 to 2011 and observe a steady process of concentration in Russian wheat exports. While, in 2003, the ten largest Russian wheat exporting firms exported less than $40 \%$ of all Russian wheat, in 2011 , they controlled roughly $70 \%$ of Russia's wheat exports. Own calculations, based on our firm-level data set provided by APK-Inform, show that the concentration of the Russian wheat export market, as measured by the ten-firm concentration ratio,

Kerstin Marit Uhl is the corresponding author

(c) BY-NC-ND $(2019$ Uhl et al., published by De Gruyter.

This work is licensed under the Creative Commons Attribution-NonCommercial-NoDerivatives 4.o License. 
declined between 2011 and 2014, yet remaining above the concentration level of 2006. This process of concentration further has nurtured concerns about a dominant market position and the assumed mark-up pricing by Russian exporters.

The emergence of Russia in international wheat markets has encouraged research regarding Russia's pricing behavior. Pall et al. (2013) are the first to conduct a study in this field. They analyze the Russian pricing behavior in international wheat trade with a pricing-to-market (PTM) study considering 25 destination countries and estimate the model for three different periods, namely the entire data period from January 2002 to February 2010, the time before the imposition of Russia's export tax on wheat exports (January 2002 to March 2007) and the time period after the export tax imposition (March 2008 to February 2010). According to their results, Russia behaves less competitively after the export tax than before. The estimation results indicate price discrimination by Russia in five to seven out of 25 export markets for the entire period in dependence on the econometric specification. More precisely, based on a model specification considering nominal exchange rate shocks, evidence for Russian price discrimination is found in Algeria, Azerbaijan, Cyprus, India and Mongolia. ${ }^{1}$

A more recent PTM study by Gafarova, Perekhozhuk, and Glauben (2015) on Kazakh, Russian and Ukrainian pricing behavior is based on aggregated data covering the period 1996-2012. They can significantly prove Russian pricing-to-market behavior in 20 out of 71 destination markets. In their PTM study on Russian pricing behavior, Uhl, Perekhozhuk, and Glauben (2016) use annual firm-level data and consider 61 export markets over the period 2002 to 2011. They find indication of price discrimination by Russian wheat exporting firms in 25 out of 61 export markets. Furthermore, Uhl, Perekhozhuk, and Glauben (2016) separately estimate the PTM model for the high-price period 2006 to 2011. These estimation results show that Russian exporters adjust to an exchange rate shock by amplifying the exchange rate effect in times of high world wheat market prices. Against the background of this result, Uhl, Perekhozhuk, and Glauben (2016) conclude that demand is less elastic in times of food scarcity.

Pall et al. (2014) apply the residual demand elasticity (RDE) approach to Russian wheat exports. As compared to the PTM model the RDE approach is more sophisticated since it takes into account both competitors' cost shifters and shifts in wheat demand in the importing countries. Concretely, Pall et al. (2014) estimate Russia's inverse residual demand elasticity for eight export markets for the period 2002 to 2009 and find support for Russian market power in Albania, Georgia and Greece, applying an instrumental variable Poisson pseudomaximum likelihood (IVPPML) estimator. Moreover, their estimation results suggest a perfectly competitive behavior in Azerbaijan, Egypt, Lebanon, Mongolia and Syria.

Previous research targeting the Russian pricing behavior in international wheat trade confirms the presence of market power in several destination markets. Yet, these destinations do not correspond with those export destinations in which Russia is able to mark-up over costs. While Pall et al. (2013) and Uhl, Perekhozhuk, and Glauben (2016) can prove Russian price discrimination in several yet different export markets, they arrive at the same result only in India where they both agree with the exertion of price discrimination. Hence, the question whether Russia possesses market power in its main export markets remains open and thus deserves further analysis and discussion. Generally, information about the competitive situation in the world wheat market is useful for policy makers in countries, which are heavily depending on wheat imports, possibly inducing a strategic realignment of national food policies. Information about the pricing behavior of wheat exporters is particularly relevant for an importing country that heavily depends on one supplier. Therefore, the aim of this paper is firstly to test for and secondly to quantify the exertion of market power by Russia in Egypt and Turkey, the two most important Russian export markets. Russia is the most important trading partner for wheat for Egypt and Turkey with a market share of about 34 percent in Egypt and about 52 percent in Turkey (average 2006-14). To arrive at these aims, we apply the RDE approach to Russian wheat export data covering the time period January 1, 2006 to December 31, 2014. As compared to the RDE study of Pall et al. (2014), the main advantage of our study is the application of weekly data while the estimates of Pall et al. (2014) rely on quarterly data. In doing so, our estimation results are based on 363 observations for Egypt and 342 observations for Turkey in contrast to only 29 observations for Egypt in the study by Pall et al. (2014). Consequently, we expect more precise estimation results. Furthermore, our data period covers both wheat price spikes in 2007/08 and 2010/11.

The rest of this paper is organized as follows. In the next section, we present a rough outline of the Russian wheat export market to better understand the choice of the export markets considered in our estimation. Sections 3 and 4 describe the RDE approach and our data set, respectively. In Section 5, we present the econometric model and discuss our estimation results. Finally, Section 6 draws conclusions. 


\section{Russian Wheat Exports}

Russia is one of the top wheat exporters worldwide. Expressed in figures, Russia's average annual export volume amounted to 14,873 thousand metric tons (average of the marketing years 2005/06 to 2014/15) or contributed to $10.7 \%$ of global wheat exports; a market share, however, that varied between $3.0 \%$ in $2010 / 11$ and $14.1 \%$ in 2014/15 (according to USDA-FAS data). Russia's export volume is strongly affected by trade policy. During our data period, Russian wheat exports were subject to several restrictions of which Table 1 gives a detailed overview.

Table 1: Restrictions of Russian wheat export activities (2006-2014).

\begin{tabular}{|c|c|c|}
\hline Type of export restriction & Period of restriction & Tax rate \\
\hline Export tax ${ }^{a}$ & 12.11.2007-28.01.2008 & $\begin{array}{l}10 \% \text { from the customs value but not } \\
\text { less than } 22 \text { Euro per } t\end{array}$ \\
\hline Export tax ${ }^{b}$ & 29.01.2008-30.06.2008 & $\begin{array}{l}40 \% \text { from the customs value but not } \\
\text { less than } 105 \text { Euro per } t\end{array}$ \\
\hline Export ban ${ }^{c}$ & 15.03.2008-30.04.2008 & - \\
\hline Export ban ${ }^{\mathrm{d}}$ & $15.08 .2010-31.12 .2010$ & - \\
\hline Export ban ${ }^{\mathrm{e}}$ & 02.01.2011-10.06.2011 & - \\
\hline
\end{tabular}

Source: a The Resolution of the Government of the Russian Federation dated October 10, 2007 № 660 “On Approval of Export Custom Tariffs on Wheat, Meslin, and Barley exported from the Territories of the Russian Federation and Members of the Custom's Union Agreement"; ${ }^{b}$ The Resolution of the Government of the Russian Federation dated October 28, 2007 № 934 "On amendments to the resolution of the government of the Russian Federation № 660 of October 10, 2007 concerning approval of export customs tariff on wheat and meslin" and the Resolution of the Government of the Russian Federation dated March 3, 2008 № 225 “On the extension of the export duties on wheat, barley and meslin". "The Resolution of the Government of the Russian Federation dated February 10, 2008 № 74 “On the introduction of a temporary ban on the export of wheat and meslin, exported from the territory of the Russian Federation in the state participants of the Customs Union"; d The Resolution of the Government of the Russian Federation dated August 5, 2010 № 559 “On the introduction of a temporary ban on the export of wheat and meslin, exported from the territory of the Russian Federation"; ${ }^{\text {eThe }}$ Resolution of the Government of the Russian Federation dated June 10, 2011 № 853 “On the introduction of a temporary ban on the export of certain types of agricultural products from the territory of the Russian Federation".

Note: The export ban established by resolution № 74 bans wheat exports to members of the Customs Union while the export bans established by resolution № 559 and resolution № 853 apply to exports to all countries.

The Government of the Russian Federation implemented a tax on wheat exports at the end of 2007. From November 12, 2007 until June 30, 2008, the export tax rate was set at $10 \%$ from the customs value but not less than 22 Euro per ton. However, on January 29, 2008, the Russian government adopted a new resolution of approval of export duty rates for wheat and meslin. According to this resolution, the export tax rate was raised to $40 \%$ from the customs value but should not be less than 105 Euro per ton. This implies that the export tax is a quantity tax if and only if the export price is not higher than 220 euro per ton in the first period of restriction and 265.5 euro per ton in the second period of restriction, respectively. Otherwise, the tax is an ad valorem tax with a tax rate of $10 \%$ or $40 \%$, respectively. Moreover, the Government of the Russian Federation banned wheat exports three times between 2008 and 2011, namely in 2008, 2010 and 2011.

In total, Russia exported wheat to 109 different countries in the period 2006 to $2014 .^{2}$ Besides Russia's relevance in global wheat trade, the interest in Russian wheat export pricing is due to its regional importance in the MENA region as well as in the Caucasus. Russia accounts for a large portion of total wheat imports of several MENA and Caucasian countries. Russia's market share in the period 2006-2014 is documented in Table 2 for selected destination markets. Table 2 indicates the high dependency of several destination countries on Russian wheat exports.

Table 2: Russia's market share in selected import markets.

\begin{tabular}{ll}
\hline Destination country & Market share (average 2006-14, in \%) \\
\hline Armenia & 87.24 \\
Azerbaijan & 42.12 \\
Egypt & 34.13 \\
Georgia & 65.56 \\
Jordan & 34.83 \\
Lebanon & 43.88 \\
Turkey & 52.40 \\
Yemen & 20.23 \\
\hline
\end{tabular}


Source: Own compilation based on import data provided by UN Comtrade (2016).

Due to this dependency the analysis of the pricing behavior of Russia is of major interest for these countries. Among Russia's export destinations, trade statistics report that wheat exports to Egypt and Turkey take an outstanding position in terms of export quantity. Figure 1 depicts the share of wheat exports to Egypt and Turkey between 2006 and 2014, and shows that exports to Egypt and Turkey account for up to half of total Russian wheat exports.

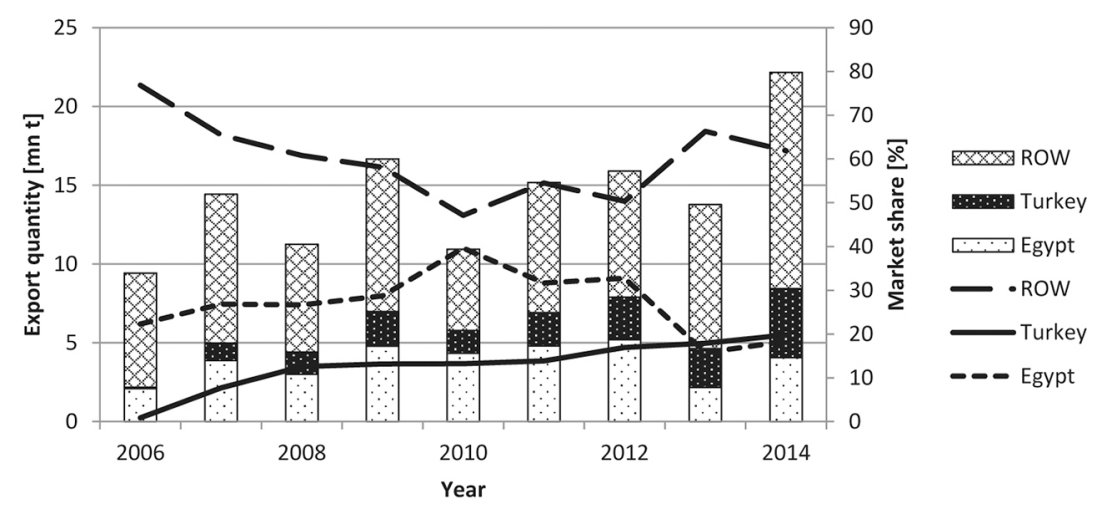

Figure 1: Russian wheat export destinations.

Source: Own compilation based on data provided by APK-Inform. Note: ROW abbreviates Rest of the World. Lines reflect market shares and bars export quantities.

Table 3 illustrates the importance of the Egyptian and Turkish market for Russian exporters. $40 \%$ of Russian wheat exports are destined for Egypt and Turkey, while the third important importer, Yemen, imports less than $4 \%$ of Russian wheat exports. Against the background of this ranking and the fact that both countries depend on Russian wheat exports, we focus our analysis on Egypt and Turkey.

Table 3: Russia's top five export destinations.

\begin{tabular}{|c|c|}
\hline Destination country & $\begin{array}{l}\text { Share in Russian wheat exports (average } \\
2006-14 \text {, in \%) }\end{array}$ \\
\hline Egypt & 26.47 \\
\hline Turkey & 13.80 \\
\hline Yemen & 3.91 \\
\hline Azerbaijan & 3.55 \\
\hline Iran & 3.51 \\
\hline
\end{tabular}

Source: Own compilation based on data provided by APK-Inform.

Figures 2 and 3 demonstrate the development of Egyptian and Turkish total wheat imports, respectively, as well as the market share of the source countries. Figure 4 depicting the trends of total Egyptian and Turkish wheat imports over the investigation period, reveal that both trends are positive, yet, Turkish wheat imports have been increasing more sharply. However, there is no clear trend regarding Russian wheat exports to Egypt within our data period. Figure 2 shows that Russia's share in Egyptian wheat imports varies between about $30 \%$ and $50 \%$. Note that while Russia is the largest exporter of wheat to Egypt, the countries France, Ukraine and the US have substantial market shares as well. In contrast to Egypt, wheat exports to Turkey have been increasing sharply in recent years. A fact that resulted from Turkey's soaring wheat import demand which could be satisfied by Russian wheat as the export quantity of other countries remained stable. Two numbers may round off this picture: in 2006, Russia exported 81,133 metric tons of wheat to Turkey, as compared to 4,387,749 metric tons in 2014. Indeed, a tremendous rise in Russian wheat exports to Turkey by more than 5,000\%. Owing to this development, today, the Turkish market is as important as the Egyptian market for Russian wheat exporters in terms of wheat export volume (see Figure 4). 


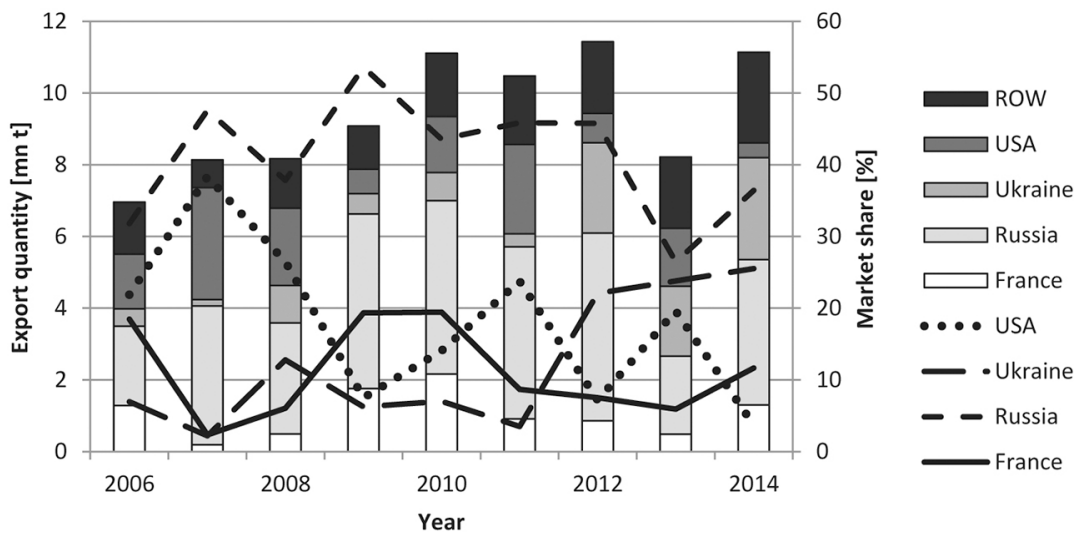

Figure 2: Total wheat exports to Egypt.

Source: Own compilation based on data provided by UN Comtrade (2016). Notes: ROW abbreviates Rest of the World. Lines reflect market shares and bars export quantities.

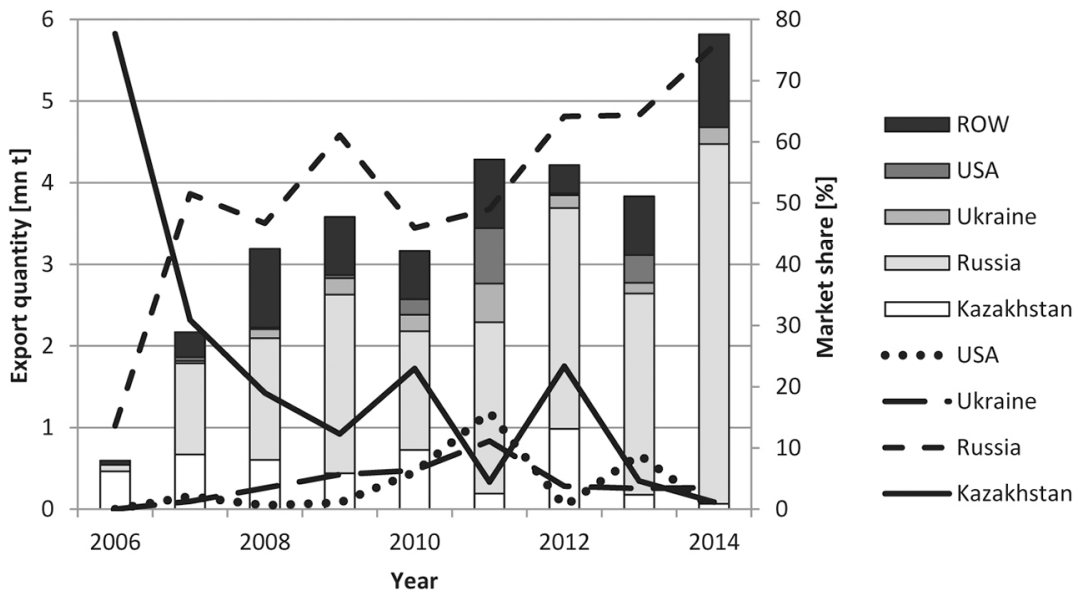

Figure 3: Total wheat exports to Turkey.

Source: Own compilation based on data provided by UN Comtrade (2016). Notes: ROW abbreviates Rest of the World. Lines reflect market shares and bars export quantities.

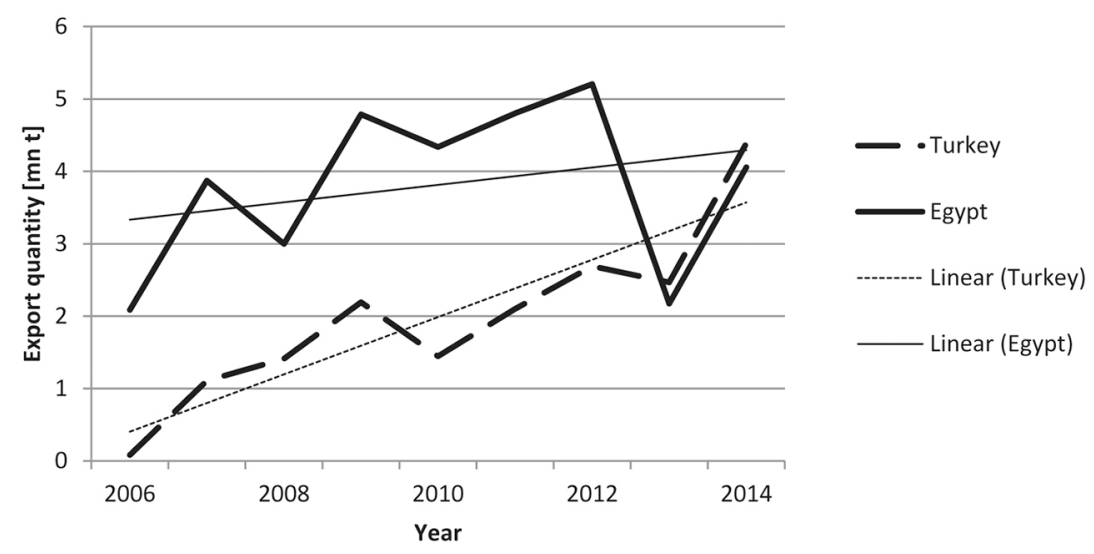

Figure 4: Russian wheat exports to Egypt and Turkey.

Source: Own compilation based on data published by UN Comtrade (2016). Note: The two lines are linear trends.

\section{The Theoretical Framework}

Our analysis is based on the RDE approach which was first introduced by Baker and Bresnahan (1988) and then popularized by Goldberg and Knetter (1999) with a prominent empirical application to international markets. Since then, there have been several agricultural market applications of the RDE model. Food commodity trade applications include Carter, MacLaren, and Yilmaz (2001) focusing on Canadian, Australian and US wheat 
exports to Japan, Mahanseth and Tauer (2014) addressing Thailand's market power in rice export destinations, Sekhar (2012) studying the exertion of market power by Thai, Chinese, Indian and US rice exporters, and finally Pall et al. (2014) conducting a RDE study targeting Russian wheat exports.

The chief advantage of the RDE method lies in its ability to disclose a seller's degree of market power by estimating a single equation, namely its residual demand curve. In this context, the term 'residual demand' means the demand a seller is facing taking into account the supply responses of all competitors. If a seller's residual demand curve is downward sloping, then the seller is not a price taker but can influence the price by choosing its quantity. Thus, the seller faces an imperfectly elastic residual demand and, consequently, possesses market power. Since the RDE methodology does not require the estimation of own- and cross-price elasticities of demand, the extent of market power can therefore be estimated with moderate data requirements. Another advantage of this approach as compared to the widely applied PTM approach is that the RDE method is based on an oligopoly model considering competitors' costs while the PTM model only assumes a simple monopoly model ignoring strategic interactions. In the following, we provide a formalization of the RDE method for the case of two exporting firms competing in the same export destination. The theoretical model is based on Baker and Bresnahan (1988).

Consider two exporting countries $(k=1,2)$ that compete in a destination market. Exporter 1 is Russia, our exporter of interest, and exporter 2 is a competitor of Russia, for instance the US. Let $P_{k}$ and $Q_{k}$ be the export price and export quantity of competitor $k$, and $Z$ be a vector of demand shifters in the destination market, for example income. The export price is expressed in the importing country's currency. Both exporters face inverse residual demand curves:

$$
\begin{aligned}
& P_{1}=P^{1}\left(Q_{1}, Q_{2}, Z\right) \\
& P_{2}=P^{2}\left(Q_{2}, Q_{1}, Z\right)
\end{aligned}
$$

Let $e_{k}$ be the exchange rate between the importing country and exporter $k . C^{k}$ is competitor $k$ 's cost function, $W_{k}$ a vector of $k$ 's cost shifters and $W$ is a vector of cost shifters relevant for all exporters. Both exporters seek to maximize their profit and they face the profit maximization problem as formalized in (3) exemplary for exporter 1 with the corresponding first order condition of the profit maximization problem for exporter 1 in (4).

$$
\begin{gathered}
\max _{Q_{1}} \Pi_{1}=Q_{1} * P^{1}\left(Q_{1}, Q_{2}, Z\right)-e_{1} * C^{1}\left(Q_{1}, W_{1}, W\right) \\
P_{1}+Q_{1} *\left[\partial P^{1} / \partial Q_{1}+\left(\partial P^{1} / \partial Q_{2}\right) *\left(\partial Q^{2} / \partial Q_{1}\right)\right]-e_{1} * M C^{1}=0
\end{gathered}
$$

The term in square brackets is the conduct parameter and represents exporter 1's conjectures about the change in $P_{1}$ induced by a change in $Q_{1}$, and therefore comprises exporter 1's conjectural variation about exporter 2's response to changes in $Q_{1}$. The value of the conduct parameter consists of two effects: a price change induced by a change in the exporter's own quantity as well as the quantity adjustment of the competitor, exporter 2. The profit maximization problem results in the optimality condition stating that marginal revenue $(M R)$ equals marginal cost $(M C)$, thereby determining the supply of the two exporters.

$$
\begin{aligned}
& M R^{1}\left(Q_{1}, Q_{2}, Z\right)=e_{1} * M C^{1}\left(Q_{1}, W_{1}, W\right) \\
& M R^{2}\left(Q_{2}, Q_{1}, Z\right)=e_{2} * M C^{2}\left(Q_{2}, W_{2}, W\right)
\end{aligned}
$$

To derive Russia's RD function, we have to solve the demand function in (2) and the expression of (6) determining the exporter's supply simultaneously in the next step. In doing so, we receive exporter 2's residual demand function, that is $Q_{2}=Q^{2}\left(Q_{1}, Z, e_{2}, W_{2}\right)$. Substituting the residual demand function in (1) yields the expression of (7), and, after dropping out redundancies, the term of (8) with $R$ terming the inverse residual demand.

$$
\begin{gathered}
P_{1}=P^{1}\left(Q_{1}, Q^{2}\left(Q_{1}, Z, e_{2}, W_{2}, W\right), Z\right) \\
P_{1}=R\left(Q_{1}, e_{2}, W_{2}, W, Z\right)
\end{gathered}
$$

The inverse residual demand of Russia in the export market is a function of the following arguments: Russia's wheat export quantity, cost shifters of Russia's competitor in the competitor's currency, cost shifters relevant 
for all exporters and demand shifters in the destination country. In order to be able to estimate (8) we rewrite the equation in its log-linear form, see (11) for the estimation equation. The coefficients in the log-linear form are interpreted as elasticities. Our parameter of interest is the inverse RDE in (9).

$$
\propto_{1}=\frac{\partial \ln R}{\partial \ln Q_{1}}=\frac{\partial R}{\partial Q_{1}} * \frac{Q_{1}}{R}
$$

By estimating the inverse RDE, we determine the joint impact of the change in wheat price induced by Russia's own change in quantity and the quantity adjustment of its rival exporter to Russia's quantity change. This becomes apparent by rewriting (9) considering the correspondence between (7) and (8):

$$
\propto_{1}=\frac{\partial \ln R}{\partial \ln Q_{1}}=\frac{\partial R}{\partial Q_{1}} * \frac{Q_{1}}{R}=\frac{\partial P^{1}}{\partial Q_{1}} * \frac{Q_{1}}{P_{1}}=\frac{\partial P^{1}}{\partial Q_{1}} * \frac{Q_{1}}{P_{1}}+\frac{\partial P^{1}}{\partial Q_{2}} * \frac{\partial Q^{2}}{\partial Q_{1}} * \frac{Q_{1}}{P_{1}}
$$

\section{Data Set Description}

To estimate our econometric model, we applied data provided by APK-Inform, a consulting company that is widely recognized in the countries of the Commonwealth of Independent States (CIS) and considered a highly reliable source of information. The data set comprised daily firm-level data on export quantities and statistical values of Russian wheat exporters for the period from January 2006 to December 2014.

Table 4 presents the descriptive statistics of the variables included in our econometric model. Please note that the descriptive statistics are based on weekly data.

Table 4: Descriptive statistics of variables.

\begin{tabular}{lllllll}
\hline Variable & $\begin{array}{l}\text { Egypt } \\
\text { Mean }\end{array}$ & Min & Max & $\begin{array}{l}\text { Turkey } \\
\text { Mean }\end{array}$ & Min & Max \\
\hline EUV & 1318.3 & 601.5 & 2273.0 & 390.1 & 204.2 & 633.2 \\
EQ & 92129.9 & 2389.5 & 460732.5 & 51815.9 & 998.0 & 210335.5 \\
Real GDP & 70.1 & 55.7 & 82.7 & 15.7 & 12.8 & 19.3 \\
CPI food & 101.1 & 96.5 & 106.4 & 100.9 & 95.6 & 105.2 \\
ER EUR & 8.0 & 6.8 & 9.7 & & & \\
ER USD & 6.0 & 5.3 & 7.1 & 1.7 & 1.2 & 2.3 \\
ER UAH & 0.8 & 0.4 & 1.1 & 0.2 & 0.1 & 0.3 \\
ER KZT & & & & 0.011 & 0.009 & 0.015 \\
EP FRA & 183.9 & 104.8 & 301.8 & & & 424.3 \\
EP USA & 241.7 & 134.2 & 433.5 & 251.4 & 160.5 & 315.0 \\
PP UKR & 1517.8 & 690.0 & 3300.0 & 1645.6 & 815.0 & 3300.0 \\
PP KAZ & & & & 24403.3 & 11868.4 & 34326.0 \\
Oil price & 99.9 & 84.8 & 122.2 & 99.9 & 84.8 & 122.2 \\
Ban KAZ & & & & 0.02 & 0 & 1 \\
\hline
\end{tabular}

Notes: EUV abbreviates export unit value, expressed in the importing country's currency. EQ terms export quantity, expressed in metric tons. ER EUR, ER USD, ER UAH and ER KZT are destination-specific exchange rates per Euro, United States Dollar, Ukrainian Hryvna, and Kazakhstani Tenge, respectively. EP FRA and EP USA denote French and US wheat export prices, respectively. PP UKR and PP KAZ are Ukrainian and Kazakh wheat producer prices. Real GDP is the real Gross Domestic Product per capita of the destination country, expressed in the importing country's currency, and CPI food denotes the Consumer Price Index for food items of the importer. The oil price is expressed as an index. Ban KAZ is a dummy variable capturing the Kazakh wheat export ban that was in force between April 27, 2008 and September 1, 2008.

Since the data set however did not contain information about costs of Russia's wheat exporters, we were not able to estimate the RDEs of single wheat exporting firms. Therefore, we had to aggregate our firm-level data to a weekly frequency. Before doing so, we eliminated seed exports because seed is typically higher-priced than non-seed wheat exports. In this step, we deleted 40 firm-level observations in case of Egypt and 46 firm-level observations in case of Turkey. Additionally, we also dropped exports of other grains than wheat from our data set.

The cost shifters included exchange rates, wheat producer or export prices of rival exporting countries as well as the oil price. The choice of exchange rates as cost shifters in international trade applications was first 
proposed by Goldberg and Knetter (1999) and is now a standard in RDE applications to agricultural export markets (see Glauben and Loy 2003; Pall et al. 2014; Reed and Saghaian 2004). Weekly exchange rate data was extracted from OANDA Forex Trading and Exchange Rates Services (see OANDA Corporation 2016), and the euro-dollar weekly exchange rate data was retrieved from the website of the Federal Reserve Bank of St Louis (see Board of Governors of the Federal Reserve System (US) (2017)). US and French wheat FOB prices in USD and Euro per ton, respectively, were collected from the Agriculture \& Horticulture Development Board (AHDB 2015) website.

Ukrainian wheat producer prices (EXW, UAH per ton) were provided by APK-Inform (see APK-Inform). The Kazakh wheat producer price (average selling price in Kazakhstani Tenge per ton) was extracted from statistical yearbooks published by the Agency of Statistics of the Republic Kazakhstan (see ASRK, Various issues). Regional wheat producer prices, which we used as an instrumental variable, covered each Russian federal district, and were provided by the Russian Grain Union. Furthermore, we used weekly oil prices (Europe Brent spot price FOB, USD per barrel) that were published by the U.S. Energy Information Administration (EIA 2016).

Demand shifters of our econometric model included the Consumer Price Indices (CPI) for food items and real Gross Domestic Products (GDP) per capita of the importing countries Egypt and Turkey. The selection of the demand shifters was similar to that of Pall et al. (2014). We applied the CPIs for food data published by FAOSTAT (2016). Since information on the real GDPs per capita was not available, we generated the necessary data from downloadable records of nominal GDPs, GDP deflators and population data from the World Development Indicators Database from the World Bank (2016). Data on GDPs and CPIs for food products were not available at weekly frequency. Therefore, we had to interpolate real GDPs per capita as well as the CPIs for food items.

\section{The Econometric Model and Estimation Results}

The RDE model was estimated in its log-linear form on the basis of the theoretical equation in (8).

$\ln P_{t}^{R U S}=\mathrm{Cons}+\alpha \ln Q_{t}^{R U S}+\beta \ln Z_{t}^{I M P}+\gamma \ln e_{t}^{C O M}+\delta \ln P P_{t}^{C O M}+\vartheta B A N_{t}^{C O M}+\varphi \ln O I L_{t}+\omega M O N T H_{t}+\varepsilon_{t}$

$P_{t}^{R U S}$ and $Q_{t}^{R U S}$ are the Russian wheat export price and export quantity in period $t$, respectively, $Z_{t}^{I M P}$ is a vector of demand shifters in the importing country (CPI for food items and the real GDP per capita), and Cons abbreviates the constant term. $e_{t}^{C O M}$ is a vector of exchange rates of Russia's competitors in Egypt and Turkey, i. e. France, Ukraine and the United States in the Egyptian market and Kazakhstan, Ukraine and the USA in Turkey. The competing wheat exporting countries were selected on the basis of their market shares in Egypt and Turkey. Table 5 gives an overview of the main wheat exporters to Egypt and Turkey over the period 2006 to 2014.

Table 5: Exporter's (Competitor's) market share (2006-14).

\begin{tabular}{lll}
\hline Destination country & Exporter/Competitor & Market share (in \%) \\
\hline Egypt & Russia & 34.13 \\
& United States & 19.70 \\
& France & 11.36 \\
Turkey & Ukraine & 7.90 \\
& Russia & 52.40 \\
& Kazakhstan & 19.04 \\
& United States & 5.54 \\
\hline
\end{tabular}

Source: Own compilation based on import data provided by UN Comtrade (2016).

$P P_{t}^{C O M}$ is a vector of producer and export prices of the set of rival exporting countries, $O I L_{t}$ denotes the oil price, $M O N T H_{t}$ is a vector of dummy variables for the months February to December, and $B A N_{t}^{C O M}$ is a dummy variable capturing Kazakh export restrictions. $\varepsilon_{t}$ is the error term and $\alpha, \vartheta$ and $\varphi$ are parameters, and $\beta, \gamma, \delta$ are vectors of parameters to be estimated. As we seek to determine the inverse RDE, our parameter of interest is $\alpha$.

Russia's wheat export quantity and export price were determined simultaneously. Therefore, the export quantity had to be instrumented. The instrument has to satisfy two properties. Firstly, it has to be relevant, that is, sufficiently correlated with the instrument, here Russia's export quantity. Secondly, it has to be valid, i. e. 
orthogonal to the error term. Consequently, a valid instrument for Russia's wheat export quantity should not have a direct impact on the export price, but an indirect by affecting the export quantity. Goldberg and Knetter (1999) proposed cost shifters of the exporter of interest that are irrelevant for other suppliers as instrument for the quantity variable. $W_{1}$, the vector of Russia's cost shifters, does not appear in (8), the theoretical equation, and are therefore valid instruments for Russia's export quantity. Russia's export tax is a valid and relevant instrument for Russia's export quantity for both, ad valorem tax and quantity tax. As a quantity tax shifts marginal cost, the export tax is a valid instrument. The validity of an ad valorem tax can be justified in a very similar way. The key point is that the introduction of the ad valorem export tax results in a shift of the supply curve of Russian wheat exporters to the left as output of Russian exporters are shrinking while demand for Russian wheat remains unaffected. These cost shifters are also relevant instruments because they affect Russia's export quantity by the first order condition (FOC) in (5). Consequently, cost shifters that are relevant exclusively for Russian exporters are theory-consistent instruments for Russia's export quantity. Therefore, we selected Russian cost shifters as instruments in our model.

Russian wheat export restrictions were specified as an instrumental variable for Egypt and Turkey. See Table 1 in Section 2 for an overview of all Russian restrictions on wheat exports. In the analysis, these restrictions were captured by a variable that was equal to the export tax, i. e. the export price multiplied by $0.10(0.40)$ in the first (second) period of restriction or 22 (105) euro converted to the USD if the export price is not more than 220 (265.5) euro per ton, and 0 if no tax is imposed. The export ban was not reflected in the instrumental variable since there were no observations for the time of the export ban. The instrumental variable specifying Russia's wheat export tax is a relevant instrument for Egypt as proved by the results of the F-test of the joint significance in the first-stage regression (see Table 6). For Turkey, we additionally selected a second instrument, namely the Russian wheat producer price for one of the main wheat producing areas of Russia for the export market, the Central Federal District. The selection of the instrumental variables for Turkey is in line with the F-test result of the joint significance in the first-stage regression and Hansen's J statistic. Please note that Hansen's J statistic could not be calculated for Egypt as there were no overidentifying restrictions.

Table 6: Validity and relevance of the excluded instruments.

\begin{tabular}{lll}
\hline & Egypt & Turkey \\
\hline Excluded instruments & Russian wheat export tax & $\begin{array}{l}\text { Russian wheat export tax } \\
\text { Russian wheat producer price } \\
\text { (Central Federal District) }\end{array}$ \\
& & $14.32[0.0000]$ \\
F-test & $11.04[0.0000]$ & $0.095416[0.7574]$ \\
Hansen's J statistic & - & \\
\hline
\end{tabular}

Notes: Numbers in square brackets are p-values. As we applied only one instrument in case of Egypt, Hansen's J statistic could not be calculated.

We applied a generalized method of moments (GMM) estimator to estimate the econometric model of (10) because of the endogeneity problem described above and since we were suspicious of heteroscedastic error terms.

The estimation results for Egypt and Turkey are listed in Table 7. Theory predicts a negative sign of the export quantity coefficient, implying a negative slope of the residual demand curve. For both export destinations, the estimated coefficient is negative, more precisely significant for Turkey, but insignificantly negative and small for Egypt. Thus, the estimation result indicates that Russia exhibits market power in Turkey but not in Egypt. This finding is in line with our a priori expectations for the following reason: In Section 2 we discussed trends in the Egyptian and Turkish wheat import market. Russia has been dominating Turkish imports in recent years with other exporters accounting only for minor market shares. In contrast, the Egyptian wheat import market is not characterized by one dominant exporter. A fact that has two important implications for the interpretation of our estimation results. First, in an oligopolistic market, a measure for the exertion of market power is the Lerner index for an entire industry that is equal to

$$
L=\frac{P-M C}{P}=\frac{H H I}{|\varepsilon|}
$$

Table 7: Estimation results.

\begin{tabular}{lll}
\hline Variable & Egypt & Turkey \\
\hline
\end{tabular}




\begin{tabular}{|c|c|c|c|c|}
\hline EQ & -0.0009 & {$[-0.032]$} & $-0.1350^{* * *}$ & {$[-6.341]$} \\
\hline Real GDP & $0.2548^{* *}$ & [2.499] & $0.3424^{* *}$ & [2.103] \\
\hline CPI food & $-1.0827^{* * *}$ & {$[-3.222]$} & -0.1385 & {$[-0.227]$} \\
\hline ER EUR & $0.5867^{* * *}$ & [7.020] & & \\
\hline ER USD & $0.4835^{* * *}$ & [3.461] & $0.5680^{* * *}$ & [4.118] \\
\hline ER UAH & $0.3767^{* * *}$ & [6.859] & $0.3693^{* * *}$ & [4.001] \\
\hline ER KZT & & & 0.0456 & [0.209] \\
\hline EP FRA & $0.5443^{* * *}$ & [9.076] & & \\
\hline EP USA & 0.0105 & [0.205] & $0.4541^{* * * *}$ & [7.665] \\
\hline PP UKR & $0.4304^{* * *}$ & [8.994] & $0.4793^{* * *}$ & [7.596] \\
\hline PP KAZ & & & $0.1029^{* *}$ & [2.329] \\
\hline Oil price & -0.1333 & {$[-1.183]$} & -0.3361 & {$[-1.502]$} \\
\hline Ban KAZ & & & 0.0072 & [0.162] \\
\hline February & 0.0014 & [0.049] & 0.0144 & [0.324] \\
\hline March & -0.0188 & {$[-0.680]$} & 0.0373 & [0.801] \\
\hline April & $-0.0694^{* * *}$ & {$[-3.256]$} & 0.0491 & [1.087] \\
\hline May & $-0.0700^{* *}$ & {$[-2.462]$} & 0.0355 & [0.692] \\
\hline June & $-0.0676^{* * *}$ & {$[-2.728]$} & -0.0208 & {$[-0.479]$} \\
\hline July & $-0.0908^{* * *}$ & {$[-3.962]$} & 0.0780 & [1.618] \\
\hline August & $-0.0710^{*}$ & {$[-1.801]$} & $0.1522^{* * *}$ & [3.105] \\
\hline September & -0.0444 & [-1.165] & $0.1427^{* * *}$ & [3.068] \\
\hline October & -0.0236 & {$[-0.774]$} & $0.0876^{* *}$ & [2.106] \\
\hline November & -0.0228 & {$[-0.770]$} & $0.0782^{*}$ & [1.942] \\
\hline December & -0.0122 & {$[-0.448]$} & $0.0806^{*}$ & [1.872] \\
\hline Constant & $3.7141^{* *}$ & [2.388] & 1.9306 & [0.641] \\
\hline $\begin{array}{l}\text { Number of } \\
\text { observations }\end{array}$ & 363 & & 342 & \\
\hline R-sq. & 0.9554 & & 0.8601 & \\
\hline Adj. R-sq. & 0.9526 & & 0.8504 & \\
\hline
\end{tabular}

Notes: See Table 4 for a detailed description of the model variables. Numbers in brackets are t-statistics.

Source: Own computations using Stata version 14.1 statistical software (StataCorp 2015).

$\varepsilon$ is the industry's price elasticity of demand and HHI is the Herfindahl-Hirschman index, a measure of market concentration. The HHI is defined as the sum of squared market shares of all sellers in the market. Consequently, the monopoly case corresponds to the HHI of 10,000 points while the HHI of a perfectly competitive market is close to zero. The Lerner index is defined as the mark-up over marginal costs and tells us that industry-wide market power increases with increasing market concentration. In the Derivation of the industry Lerner index we show that the Lerner index for an entire industry, as expressed in (12), is a special case of our RDE model. Table 8 displays the HHI for Egypt and Turkey based on state-level export data. The United States Department of Justice defines the following ranges of market concentration: a market with the HHI between 1,500 and 2,500 points is moderately concentrated while a highly concentrated market is characterized by the HHI above 2,500 points. We expected a higher degree of market power in Turkey than in Egypt. Indeed, the calculated HHI indicates the wheat import market of Egypt to be moderately concentrated but a high degree of market concentration for Turkey. Consequently, our results are in line with theoretical expectations.

Table 8: Herfindahl-Hirschman index.

\begin{tabular}{lllllllllll}
\hline & $\mathbf{2 0 0 6}$ & $\mathbf{2 0 0 7}$ & $\mathbf{2 0 0 8}$ & $\mathbf{2 0 0 9}$ & $\mathbf{2 0 1 0}$ & $\mathbf{2 0 1 1}$ & $\mathbf{2 0 1 2}$ & $\mathbf{2 0 1 3}$ & $\mathbf{2 0 1 4}$ & $\boldsymbol{\varnothing}$ \\
\hline Egypt & 1,992 & 3,780 & 2,435 & 3,381 & 2,579 & 2,833 & 2,753 & 1,954 & 2,403 & 2,343 \\
Turkey & 6,256 & 3,654 & 2,746 & 4,026 & 2,765 & 2,842 & 4,690 & 4,305 & 5,807 & 3,675 \\
\hline
\end{tabular}

Source: Own compilation based on state-level export data provided by UN Comtrade (2016).

Second, for a single seller, there is a direct relationship between the inverse RDE and the Lerner index, which is expressed in a Consistent Conjectures Equilibrium (CCE), as outlined by Baker and Bresnahan (1988). CCE means that each seller has correct conjectures about all competitors' responses to its actions (Bresnahan 1981). In a CCE, the Lerner index is equal to the inverse RDE of seller $k,-\alpha_{k}$, as can be shown by rearranging (4).

$$
L=\frac{P_{k}-e_{k} * M C^{k}}{P_{k}}=-\alpha_{k}
$$


One might argue that minor exporters in the Turkish market would follow the Russian price-setting behavior, so that Russia has consistent conjectures about the behavior of its competitors. Consequently, there is a direct relationship between the estimated inverse RDE and the Lerner index, which is revealed by the estimated markup over marginal costs of $13.5 \%$.

Turning to the competitors' cost shifter variables including exchange rates as well as wheat producer and export prices. The sign of these coefficients gives insight into the degree of competition with Russian wheat. However, the exchange rate variables are likely to be correlated as shocks to the Egyptian/Turkish economy affect the exchange rates of the Egyptian Pound/Turkish Lira against all other currencies. Therefore, we should be careful with the interpretation of the coefficients of the exchange rate variables as standard errors of collinear variables are increased.

Positive coefficients mean that Russia charges higher prices after a cost shock that reduces the competitiveness of other suppliers. This implies that Russian price setting was more restricted before the cost shock. Thus, the positive sign of the estimated coefficient suggest that Russia's price-setting scope is indeed bounded. The positive exchange rate coefficient implies that Russia sets higher export prices after an appreciation in the competitor's currency. We see that all exchange rate coefficients reveal a positive sign and, apart from Kazakhstan, are significantly different from zero. This finding suggests that the competitors sell a close substitute to Russian wheat, thereby restricting Russian market power. Furthermore, all producer and export price coefficients have a significantly positive sign with the exception of the US wheat export price in case of Egypt. A positive producer or export price indicates that Russia is able to charge higher prices when costs of the competing country are rising. The coefficient of the oil price variable, a cost shifter that applies to all exporters, is insignificantly different from zero. To conduct a robustness check, we re-estimated our econometric model without the oil price variable. As a result, our estimations are robust to the exclusion of the oil price variable.

As demand shifters of the importing country, we included the real GDP per capita as well as the CPI for food items. The coefficient for real GDP per capita exhibits a significantly positive sign in both importing countries, suggesting that an increase in income boosts demand in wheat. The CPI for food items is negative in both countries. This implies that inflation in food prices leads to a lower demand for wheat, a result that is completely in line with economic theory. The effect is significant in case of Egypt but insignificant in case of Turkey. Egypt imports wheat for domestic consumption while Turkey uses a substantial share of its wheat imports for processing wheat and exporting the processed products. Therefore, demand for wheat is less sensitive to domestic food price inflation in Turkey.

\section{Conclusion}

Russia has emerged as a major wheat exporter since the turn of the millennium, and today holds significant market shares in several wheat importing countries in the MENA region as well as in the Caucasus. Russia's dominance in some wheat import-dependent countries raises the question whether Russia exploits its dominant market position. This concern is particularly relevant in times of high world wheat market prices as market power may contribute to high and volatile prices.

We apply Baker and Bresnahan's (1988) residual demand elasticity method to Russian wheat exports to Russia's two main destination markets Egypt and Turkey. The RDE approach allows estimating the extent of market power of an exporter by estimating a single equation, the residual demand curve. Moreover, the approach considers cost shifts of all competing exporters as well as demand shifts in the importing country. According to our estimation results, Russia behaves competitively in Egypt and there is Russian mark-up pricing in Turkey with an estimated mark-up of $13.5 \%$. The results are in line with our a priori expectations since Russia has been dominating the Turkish wheat import market for the last years. The situation is different with Egypt where there are also other exporting countries with significant market shares in the Egyptian wheat import market, thus limiting Russian market power. Our estimation results are in line with the results of a pricing-to-market study by Uhl, Perekhozhuk, and Glauben (2016) who have found evidence for Russian price discrimination in Turkey but none for Egypt for the period 2002 to 2011.

The presence of Russian market power in Turkey does not necessarily have negative implications for food security in Turkey. While Egypt imports wheat mainly for domestic consumption, Turkish wheat imports are further processed and then re-exported. Therefore, higher wheat export prices for Turkey do not directly affect Turkish consumers. In conclusion, since our results concern only a limited scope of Russian wheat exports, this issue still merits a closer inspection. 


\section{Funding}

This work has been developed in the project "Global Food Security and the Grain Markets in Russia, Ukraine and Kazakhstan (GERUKA)“ (reference number: 2811HS023) and is partly funded by the Bundesministerium für Ernährung und Landwirtschaft, Bundesanstalt für Landwirtschaft und Ernährung.

\section{Notes}

1 The PTM approach infers market imperfections from price discrimination. See McAfee, Hugo, and Mialon (2006) and Levine (2002) for a discussion about the relationship between price discrimination and market power.

2 The regions Abkhazia and South Ossetia are recognized as independent countries by Russia.

\section{References}

Abbott, P. C., C. Hurt, and W. E. Tyner. 2011. “What's Driving Food Prices in 2011?” Farm Foundation Issue Report.

AHDB. 2015.“Agriculture \& Horticulture Development Board." Warwickshire, UK. http://www.ahdb.org.uk.

APK-Inform. "Agribusiness Information Consulting Company APK-Inform." Dnipropetrovsk, Ukraine. Accessed 2015. www.apk-inform.com.

ASRK. Various issues. Agency of Statistics of the Republic Kazakhstan. Statistical Yearbooks "Prices in Agriculture, Forestry and Fisheries in the Republic of Kazakhstan" (Various Issues). Astana, Kazakhstan.

Baker, J. B., and T. F. Bresnahan. 1988. "Estimating the Residual Demand Curve Facing a Single Firm." International Journal of Industrial Organization $6(3): 283-300$.

Board of Covernors of the Federal Reserve System (US). “U.S./Euro Foreign Exchange Rate [DEXUSEU]." FRED, Federal Reserve Bank of St Louis. Accessed August 14, 2017. https://fred.stlouisfed.org/series/DEXUSEU.

Bresnahan, T. F. 1981. "Duopoly Models with Consistent Conjectures.” The American Economic Review 71 (5):934-945.

Carter, C. A., D. MacLaren, and A. Yilmaz. 2001. "How Competitive Is the World Wheat Market?" IIFET Conference Papers and Presentations.

EIA.2016. "U.S. Energy Information Administration - Statistical and Analytical Agency within the U.S. Department of Energy." Europe Brent Spot Price FOB (Dollars per Barrel). http://www.eia.gov/.

FAOSTAT. 2016. "Statistics Division of the Food and Agriculture Organization of the United Nations." http://faostat3.fao.org/home/E.

Gafarova, G., O. Perekhozhuk, and T. Glauben. 2015. "Price Discrimination and Pricing-to-Market Behavior of Black Sea Region Wheat Exporters." Journal of Agriculture and Applied Economics 47 (3):287-316.

Glauben, T., and J.-P. Loy. 2003. "Pricing-to-Market versus Residual Demand Elasticity Analysis of Imperfect Competition in Food Exports: Evidence from Germany." Journal of Agricultural and Food Industrial Organization 1 (1):1-19.

Coldberg, P. K., and M. M. Knetter. 1999. “Measuring the Intensity of Competition in Export Markets." Journal of International Economics 47 (1):27-60.

Levine, M. E. 2002. “Price Discrimination without Market Power." Yale Journal on Regulation 19 (1):1-36.

Mahanseth, I., and L. W. Tauer. 2014. “Thailand's Market Power in Its Rice Export Markets." Journal of Agricultural \& Food Industrial Organization 12 (1):109-120.

McAfee, R. P., H. M. Hugo, and S. H. Mialon. 2006. “Does Large Price Discrimination Imply Great Market Power?.” Economics Letters 92 (3):360367.

Mitchell, D. 2008. “A Note on Rising Food Prices.” Policy Research Working Paper No. 4682. Washington, DC: World Bank.

OANDA Corporation. 2016. "Forex Trading and Exchange Rates Services." www.oanda.com.

Pall, Z., O. Perekhozhuk, T. Glauben, S. Prehn, and R. Teuber. 2014. “Residual Demand Measures of Market Power of Russian Wheat Exporters." Agricultural Economics 45 (3):381-391.

Pall, Z., O. Perekhozhuk, R. Teuber, and T. Clauben. 2013. "Are Russian Wheat Exporters Able to Price Discriminate? Empirical Evidence from the Last Decade." Journal of Agricultural Economics 64 (1):177-196.

Reed, M. R., and S. H. Saghaian. 2004. "Measuring the Intensity of Competition in the Japanese Beef Market." Journal of Agricultural and Applied Economics 36 (1):113-121.

Sekhar, C. S. C. 2012. "Market Power and World Price: The Role of Asian Rice Exporters." Journal of International Food \& Agribusiness Marketing 24:3.

StataCorp. 2015. Stata Statistical Software: Release 14. College Station, TX: StataCorp LP.

Trostle, R., D. Marti, S. Rosen, and P. Westcott. 2011. “Why Have Food Commodity Prices Risen Again?” USDA Economic Research Service. Outlook No. WRS-1103.

Uhl, K. M., O. Perekhozhuk, and T. Glauben. 2016. “Price Discrimination in Russian Wheat Exports: Evidence from Firm-Level Data." Journal of Agricultural Economics 67 (3):722-740.

UN Comtrade. 2016. “United Nations Comtrade Database - International Trade Statistics." http://comtrade.un.org.

USDA-FAS. "United States Department of Agriculture, Foreign Agricultural Service. "Crain: World Markets and Trade", Issues from 2004 to 2016." www.fas.usda.gov.

World Bank. 2016. "World Development Indicators Database." www.worldbank.org.

Wright, B. D. 2011. “The Economics of Grain Price Volatility." Applied Economic Perspectives and Policy 33 (1):32-58. 


\section{Appendix}

\section{A Derivation of the industry Lerner index}

In the following, we show that the Lerner index for an entire industry, as expressed in (12), is a special case of the RDE model from Section 3. For this purpose, we need the following assumptions:

1. There is one single market price, thus $P_{1}=P^{1}\left(Q_{1}, Q_{2}, Z\right)=P^{2}\left(Q_{2}, Q_{1}, Z\right)=P\left(Q_{2}, Q_{1}, Z\right)$.

2. The products are perfect substitutes. Therefore, the inverse demand function can be rewritten the following way: $P\left(Q_{2}, Q_{1}, Z\right)=P\left(Q_{2}+Q_{1}, Z\right)=P(Q, Z)$.

3. We assume zero conjectural variations in quantity. Thus, $\frac{\partial Q^{2}}{\partial Q_{1}}=0$.

4. Demand functions are linear.

The profit maximization problem for exporter 1 is then equal to $\max _{Q_{1}} \Pi_{1}=Q_{1} * P^{1}\left(Q_{1}+Q_{2}, Z\right)-e_{1} *$ $C^{1}\left(Q_{1}, W_{1}, W\right)$. Since $\frac{\partial Q}{\partial Q_{1}}=\frac{\partial Q}{\partial Q_{2}}=1$ due to assumption (3) we can rearrange the first order condition (FOC) to the following expression: $\frac{P-e_{1} * M C^{1}}{P}=-\frac{Q_{1}}{P} * \frac{\partial P}{\partial Q}$ that is equal to the Lerner index for a single seller. The industry Lerner index is computed as the sum of the market share-weighted Lerner indices for all sellers. In our two-exporter example, the industry Lerner measure is equal to:

$L=s_{1} * \frac{P-e_{1} * M C^{1}}{P}+s_{2} * \frac{P-e_{2} * M C^{2}}{P}$ with $s_{1}=\frac{Q_{1}}{Q}$ and $s_{2}=\frac{Q_{2}}{Q}$. Inserting the expression for the FOC yields $=s_{1} *\left[-\frac{Q_{1}}{P} * \frac{\partial P}{\partial Q}\right]+s_{2} *\left[-\frac{Q_{2}}{P} * \frac{\partial P}{\partial Q}\right]$. We multiply this expression by $\frac{Q}{Q}$ and thereby we obtain $=s_{1} * \frac{Q_{1}}{Q} *$ $\left[-\frac{Q}{P} * \frac{\partial P}{\partial Q}\right]+s_{2} * \frac{Q_{2}}{Q} *\left[-\frac{Q}{P} * \frac{\partial P}{\partial Q}\right]=\sum_{i=1}^{2} s_{i}^{2} *\left(-\frac{Q}{P} * \frac{\partial P}{\partial Q}\right)=H H I *\left|\frac{Q}{P} * \frac{\partial P}{\partial Q}\right|$. As we assume linear demand functions it is $\left|\frac{\partial P}{\partial Q}\right|=\left|\frac{1}{\partial Q / \partial P}\right|$ and we can retype the expression for the Lerner measure as expressed in (12): $L=H H I *$ $\frac{1}{\left|\frac{\partial Q}{\partial P} * \frac{P}{Q}\right|}=H H I * \frac{1}{|\varepsilon|}$ with $\varepsilon$ abbreviating the price elasticity of demand. 